\title{
Interference of Bilirubin in the
}

\section{Determination of Magnesium with Methyl Thymol Blue}

\author{
Rada Maksinovic', Sonja Ketin², Rade Biocanin³ \\ 'International University of Travnik, Bosnia and Herzegovina \\ ${ }^{2}$ Faculty of Technical Science, University of Novi Sad, Serbia \\ ${ }^{3}$ State University of Novi Pazar, Serbia \\ Corresponding author: Rada Maksinovic. International University of Travnik, Bosnia and Herzegovina.
}

\begin{abstract}
Introduction: Jaundice is a disease named for the yellow color of the skin. This color is the result of elevated levels of bilirubin in the blood serum. In Roma from Krusevac region in the last few years have seen the emergence of jaundice. Material and methods: In 80 of them ( 40 suffering and 40 from control group) were performed tests of numerous parameters in the laboratories of the Health Center in Krusevac. Magnesium was determined by spectrophotometry with methyl thymol blue, titanium yellow and blue xylidene. Bilirubin was determined by Jandrešek Grofov's method. Results: The results were within the expectations, in addition to magnesium which was determined with methyl thymol blue. In all patients suffering from jaundice concentration of magnesium $(0.67 \pm 0.14 \mathrm{mmol} / \mathrm{l})$ statistically was significantly lower than tested of the control group $(0.91 \pm 0.059 \mathrm{mmol} /)$. There is no theoretical data to reduce the concentration of magnesium in serum as a result of jaundice. That's why we determined magnesium both in the control group and in sufferings with two methods as the titanium yellow, and xylidene blew. With these two methods we obtained results that were examined were within normal limits. Conclusion: This has led us to conclude that the determination of bilirubin interferes with magnesium methyl thymol blue.
\end{abstract}

Key words: Bilirubin, Methyl thymol blue, xylidene blue, titanium yellow.

\section{INTRODUCTION}

Jaundice is a disease named for the yellow color of the skin (1-7). This color is the result of elevated levels of bilirubin in the blood serum. Elevated concentration of bilirubin interferes with the determination of magnesium with methyl thymol blue, and it is a method that is widely represented in biochemical laboratories (7-14).

Magnesium is a very important element for many biological processes in plant and animal life. It is located in the center of the complex bound of the metalloporphyrin chlorophyll, which means that its presence is necessary for photosynthesis, the process that is the basis of life on earth. Magnesium ion is an important cofactor and many vital enzymatic processes, such as, for example, transfer and hydrolysis of phosphate groups, with the participation of hexokinase, the alkaline phosphatase from the red blood cells and bone and prostatic acid phosphatase. The transfer of energy of magnesium is associated with adenosine triphosphate in Mg-ATP complex.

In addition, all types of muscle contractions depend on the action and the interaction of the magnesium and calcium salts, and these two cations play an important role in motility of cells, the activities of nerve cells, the regulation of cell metabolism, transport, and secretion of fluid and ions. The function of smooth muscle of the heart and the pressure in the blood vessel are directly dependent on the modulatory role in the mobility and translocation of calcium in the cell membrane of the heart muscle and intercellular space. (1). Magnesium maintained in subpharmacological doses stabilize arrhythmia, lowers blood pressure, increases the force of the heart reduces myocardial force. At the cell level magnesium changes transport of sodium and probably prevents the entry of sodium and calcium in cells. It also suppresses the influence of catecholamines, and plays the role of protector of cardiotoxic substances and stress. Magnesium and calcium strongly metabolized, and for its biological activity, it is sufficient in the presence of trace amounts. Unlike calcium, magnesium levels in the plasma is not a hormoneregulated, or the $\mathrm{Mg} 2+$ cation motile $(1,2)$.

Magnesium is essential for the activity of more than 300 enzyme, such as alkaline phosphates, peptidase, and enzyme systems involved in the transfer of phosphate. Hydrolysis of ATP to ADP is one of the most important catalytic role of $\mathrm{Mg}$. Lack of $\mathrm{Mg}$ can lead to a reduction in the integrity and function 
of membranes and increases the possibility of oxidative stress, cardiovascular disease, cancer, and leads to accelerated aging.

Deficit $\mathrm{Mg}$ causes increased production of free radicals in terms of lack of $\mathrm{Mg}$ leads to a significant increase in lipid peroxidation that is, malondialdehyde MDA in plasma and liver. Deficit of Mg just after a few weeks leads to a reduction of GSH in erythrocytes, causing a decrease in ascorbate in the liver, brain and other tissues. Since ascorbate regenerate vitamin E from the reduced and oxidized forms, the loss of ascorbate suggest a possible loss of the reduced form of vitamin E.

\section{METHODS AND EXAMINEES}

\subsection{Methods for the determination of magnesium}

Magnesium was determined by spectrophotometry with methyl thymol blue, titanium yellow and blue xylidene $(3,4$, 5). Bilirubin was determined by Jandrešek Grofov's method (6).

\subsection{Examinee}

The subject of study was part of the Roma population in the municipality of Krusevac. In them, for few years occur jaundice. We examined them 80 , including 40 suffered of jaundice and 40 healthy, who were in the control group.

\section{RESULTS AND DISCUSSION}

In both groups of the examinees were determined numerous hematological and biochemical factors. In this paper, we focused on the determination of magnesium with methyl thymol blue. Magnesium was only one of the parameters that were determined, and we expected to be within the reference range $(0.8-$ $1.09 \mathrm{mmol} / \mathrm{L})$. And so it was for the control group in which the concentration of magnesium was $(0.91 \pm 0.059 \mathrm{mmol} / \mathrm{L})$.

However, in patients suffering from jaundice we obtained significantly lower values for the concentration of magnesium $(0.67 \pm 0.14 \mathrm{mmol} / \mathrm{L})$ compared to the reference value. How we did not find the literature data that the appearance of jaundice is accompanied by decrease of the concentration of magnesium, we decided to determine the magnesium with two other methods. In order to verify the correlation between these methods, we made standard solutions of magnesium ( 0.25 to $3.0 \mathrm{mmol} /$ L). Each standard solution was determined by magnesium with all three methods.

By comparing the values of magnesium determined by method with methyl thymol blue $(\mathrm{X})$ and the method with xylidene blue $(\mathrm{Y})$, we get the following equation right:

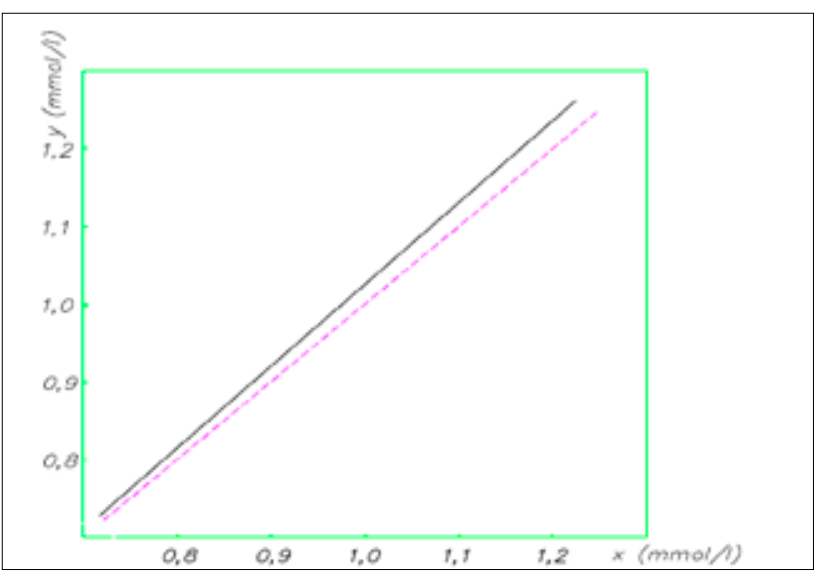

Figure 1. The correlation method for the determination of magnesium, the method with methyl thymol blue $(X)$, the method xylidene blue $(Y)$

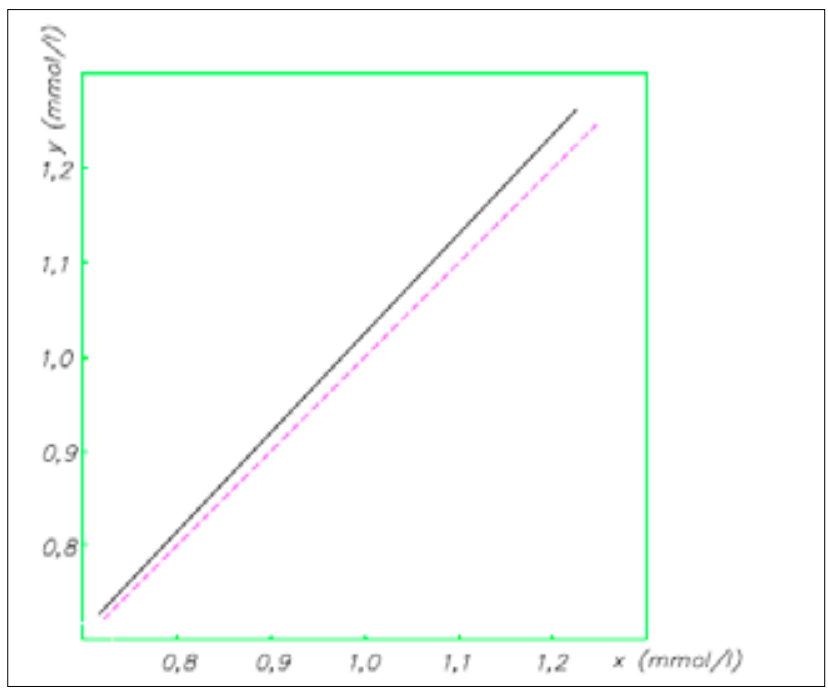

Figure 2. The correlation method for the determination of magnesium, the method with methyl thymol blue $(X)$ and xylidene blue

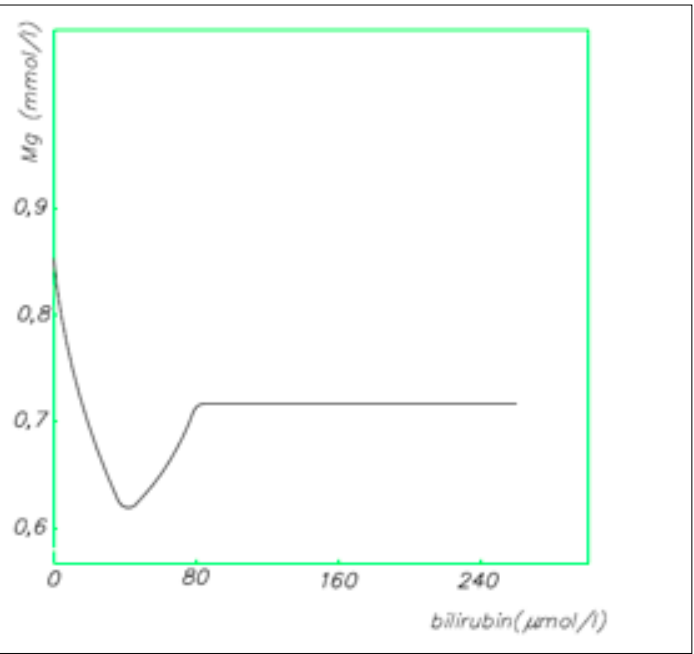

Figure 3. Interference of bilirubin in the determination of magnesium with metal thymol blue.

$$
\begin{array}{ll}
Y=-0.0133+1.0255 X \\
S_{x, y=0.0273} & r=0.976 \\
S_{a=0.02996} & t_{a=-0.444} \\
S_{b=0.03298} & t_{b=0.773}
\end{array}
$$

From the given parameters can be seen that these two methods agree within the specified range of values.

From the values obtained by determining the magnesium method with methyl thymol blue $(X)$ and titanium yellow $(Y)$, calculated by the equation right which reads:

$$
\begin{array}{ll}
S_{x, y}=0.0314 & r=0.967 \\
S_{a=0.02857} & t_{a=5.999} \\
S_{b=0.03297} & t_{b=5.904} \\
p<0.01 & \\
p<0.01 &
\end{array}
$$$$
\mathrm{Y}=0.1714 \pm 0.8151 \mathrm{X}
$$

As can be seen from the calculated values there is a slight discrepancy between the obtained results, and the difference is expressed in the following way: up to concentrations of 0.93 $\mathrm{mmol} / \mathrm{L}$ method with titanium yellow gives more, and above concentrations of $0.93 \mathrm{mmol} / \mathrm{L}$ lower values.

A value of $0.93 \mathrm{mmol} / \mathrm{L}$ is located in the middle of the reference interval, so that the actual difference between the two 
methods at the lower and upper end of the reference range is not significant. These results are shown in Figures 1 and 2.

When we found that the correlation between the methods good we determined magnesium in patients suffering of jaundice and in the control group both with the methyl thymol blue and titanium with yellow and blue xylidene. With the method of titanium yellow we get similar values of magnesium $(0.92 \pm$ $0.081 \mathrm{mmol} / \mathrm{L}$ ) in the control group as in the determination of magnesium with methyl thymol blue, and significantly different values in patients with jaundice.

In patients with jaundice concentration of magnesium the determined titanium yellow was $(0.92 \pm 0.075 \mathrm{mmol} / \mathrm{L})$. The concentration of magnesium $(0.90 \pm 0.84 \mathrm{mmol} / \mathrm{L})$ determined with xylidene blue was similar to values obtained with the two mentioned in the control group.

Also was similar values $(0.92 \pm 0.068 \mathrm{mmol} / \mathrm{L})$ obtained with titanium yellow in patients with jaundice, and significantly different from the above results obtained by means of methyl thymol blue. Based on these results we can conclude that the bilirubin that was significantly elevated in patients with jaundice strongly interferes with the determination of magnesium metal with thymol blue.

\section{CONCLUSION}

The subject of our study were members of the Roma population from Krusevac, and that 40 of them with jaundice, and 40 healthy examinees. There was performed measurement of the concentration of magnesium with the aim of interference of bilirubin.

In the control group, i.e. examinees who did not have jaundice were obtained results in the framework of reference, while in patients suffering from jaundice was noticeably reduced the concentration of magnesium.

Using the above method of determining the concentration of magnesium can be concluded that the interference of bilirubin which is significantly elevated in patients with jaundice strongly interfere with the determination of the concentration of magnesium metal with thymol blue.

\section{CONFLICT OF INTEREST: NONE DECLARED.}

\section{REFERENCES}

1. Maksimovic R, Osnovi medicinske biohemije, Aperion, Banja Luka, 2010.

2. Spasić S, Jelić-Ivanović Z, Spasojević-Kalimanovska V. Medicinska biohemija. Farmaceutski fakultet, Beograd, 2004.

3. Spasić S, Jelić-Ivanović Z, Spasojević-KalimanovskaV. Praktikum iz medicinske biohemije, Farmaceutski fakultet, Beograd, 2005.

4. Simić T, Marković I, Petronijević N, Isaković A.Priručnik za vežbe iz biohemije, Medicinski fakultet, Beograd, 2008.

5. Caplan LA, Pesce JP, Kazmierzak CK. Clinical Chemistry, 4th ed., Mosby, Maryland Heights, Missouri, 2004.

6. Mann CK, Yoe JH. Anal. Clin. Acta, 1957; 16: 155. Standard Methods of Clin. Chem. vol Academic Press New York, 1965: 137.

7. Thuvasethakul P, Wajjwalku W. Serum Magnesium Determined by Use of Methylthymol Blue, Clin. Chem. 1987; 33: 614-615.

8. Friedman and Young. Effects of disease on clinical laboratory tests, 3th ed. AAcc press, NY, 1997.

9. Pearlman FC, Lee PPY. Detection and measurement of total bilirubin in serum, with use of surfactants as solubilizing agents. clin. chem. 1974; 20: 447-453.

10. Maksimovic R. Hemija u zdravstvu, Aperion, Banja Luka, 2011.

11. Li Q, Cheng T, Wang Y, Bryant SH. PubChem as a public resource for drug discovery.. Drug Discov Today. 2010; 15(2324): 1052-1057. DOI:10.1016/j.drudis.2010.10.003. PMID 20970519.

12. Evan E. Bolton, Yanli Wang, Paul A. Thiessen, Stephen H. Bryant. "Chapter 12 PubChem: Integrated Platform of Small Molecules and Biological Activities". Annual Reports in Computational Chemistry. 2008; 4: 217-241. DOI:10.1016/S15741400(08)00012-1.

13. Hettne KM, Williams AJ, van Mulligen EM, Kleinjans J, Tkachenko V, Kors JA. Automatic vs. manual curation of a multi-source chemical dictionary: the impact on text mining. J Cheminform. 2010; 2(1): 3. DOI:10.1186/1758-2946-2-3. PMID 20331846.

14. Gaulton A, Bellis LJ, Bento AP, Chambers J, Davies M, Hersey A, Light Y, McGlinchey S, Michalovich D, Al-Lazikani B, Overington JP. ChEMBL: a large-scale bioactivity database for drug discovery. Nucleic Acids Res 40 (Database issue): D1100-7.2012. DOI:10.1093/nar/gkr777. PMID 21948594. 